\title{
Roots and Routes: Road from Home to America, Middle East and Diaspora, about Being Armenian Genocide Female Survivor
}

\author{
Ani Derderian Aghajanian \\ Washington State University \\ E-mail: ani.ag@hotmail.com
}

Received: February 11, 2011 Accepted: February 28, 2011 doi:10.5539/ies.v4n3p66

\begin{abstract}
Adolf Hitler, on August 22, 1939 stated, "I have given orders to my Death Units to exterminate without mercy or pity men, women, and children belonging to the Polish-speaking race. It is only in this manner that we can acquire the vital territory which we need. After all, who remembers today the extermination of the Armenians?" (Kherdian, 1979).

Armenia is a land which has been ravaged by war on far too many occasions. Other nations keep turning it into a battlefield and tearing it apart. Armenian people have survived for many generations and their stories are told and retold during the hard winters. Armenians' survived just as Armenia and Armenian culture have survived (Downing, 1972). Therefore, diverse life experience, traditions, histories, values, world views, and perspectives of the diverse cultural groups make up a society and preserve culture (Mendoza and Reese, 2001).

In this study, two Armenian books "The Road from Home" and "The Knock at the Door" were analyzed. These books are organized as personal stories and experiences about Armenian female genocide survivors and are supplemented by background information on Armenian people before and after the genocide of their culture, including a brief history, discussion of traditions, recipes, music and religion. These stories are a great resource for educators, historians, students, and anyone interested in Armenian culture. That is culture is an historical process of humanity that preserves identity and ties the people together. Additionally, culture is the link between people and their value systems. Therefore, Norms and values addressed in stories are important factors that give continuity to cultures (Stephens, 1992).
\end{abstract}

Keywords: Armenians, Genocide, Middle East, Ottoman Empire, Culture, Gender

\section{Armenia}

There are several Armenias. Armenia has undergone numerous transformations, from The Kingdom of Armenia, to the Armenia of the Roman, Byzantine, Persian, Turkish, and Russian periods. Leading up to the Treaty of Sevres, a Wilsonian Armenia was created on paper when America considered taking Armenia under her protective wing; however, the treaty was ultimately rejected. There is also the Armenia of the Soviet Socialist Republic (SSR), and the Armenian Diaspora, with colonies all over the world (Surmelian, 1968, p.23-24). Since the collapse of Soviet Union there are two republics; Republic of Armenia and Republic of Artsakh (Nagorno-Karabakh). (Armenian National Committee of America [ANCA], 2010).

What can we say about Armenia? Surmelian (1968) p.23-24 stated,

There is no other country like her. She has played a unique and perhaps indispensable role as a buffer between Asia and Europe, a mediator between two seemingly irreconcilable civilizations and ways of life. Armenia can be viewed as a dream, a vision, and her dark beauty is eternal.

Armenia lies in the highlands surrounding the Biblical mountains of Ararat, upon which, according to the Bible, Noah's Ark came to rest after the flood (The Armenian General Benevolent Union [AGBU], 2010). Christianity spread into the country as early as AD 40. King Tiridates III (AD 238-314) made Christianity the state religion in AD 301, becoming the first officially Christian state (The Armenian General Benevolent Union [AGBU], 2010).

In the period 1915 Armenians were exposed to systematic and deliberate extermination. Therefore this is a turning point in the Armenian history (The Armenian General Benevolent Union [AGBU], 2010); To Armenians, especially for the senior members of the community, April 24 is a day of mourning and remembrance. To the young generation, it is a day to openly profess their Armenian heritage, express themselves as Armenians and demand justice for their ancestral loss to remind the world about the first genocide of the $20^{\text {th }}$ century.

\subsection{Research Questions}

For the purpose of this study I considered the following questions: 
i. How do the chosen books "The Road from Home" and "The Knock at the Door" represent the Armenian culture and history specifically in Western Armenia?

ii. What is the message within each book that relates to cultural values?

\subsection{Methodology}

For the purpose of this study, two samples of Armenian books, "The Knock at the Door" and "The Road from Home," were chosen.

These personal stories represent the Armenian culture and history. They pay particular attention to Armenian women who survived the genocide and reached the USA in the 1915's and 1920's either by false passports or as a mail ordered brides (Ajemian-Ahnert, 2007; Kherdian, 1979). The previously mentioned books point out the similarity between Armenian women's sufferings, their shared experiences and stories during the genocide, the setting and the message. In addition, I interviewed second generation female genocide survivors from the Middle East-Jordan and shared their experiences in the post war era and the national reconstruction stage. To be an insider helped me as I am familiar with the Armenian culture and can represent it correctly.

\subsection{The Knock at the Door}

In her book, Margaret Ajemian-Ahnert illustrates her mother's experience during the period of 1915 and shows how her mother began to have flashbacks about the Armenian genocide which she had survived years before. Ajemian-Ahnert mentions her visit to Armenia with her mother who became traumatized as a result of her experiences and refused to speak a single Armenian word. Moreover, Ajemian-Ahnert mentions, "Her father always wanted them not to speak about the genocide." My explanation here is from the Armenian saying: "When the past is behind you, keep it there." However, Ajemian-Ahnert, a producer of television documentaries, interviewed her 98-year-old mother, Ester, a survivor of the massacres, and analyzed her mother's vivid recollections of the period with her own memories. In her book, Ajemian-Ahnert describes the chaos and the violence of the Ottoman Empire. Specifically, she describes the situation the abducted Armenian women and girls were in and how they married Muslims during the deportation to survive in the complex conditions prevailing in this period (Tachjian, 2009, p. 74).

Mikayel Natanian, a representative to recover Armenian women from Muslim families in Syria, wrote the following interesting letter dated June 1919.

Tachjian (2009) stated,

If older girls and women want to come, there is no problem. If they do not come,

there is still no problem: they do well to stay where they are. They are of no use to us, and may even be harmful. I have seen many who are already adults and do not come willingly...The sad and, for us, important thing is the very young children: the boys.

The previous letter reveals gender discrimination and shows the difficulty of passing the cleansing stage of Armenians in addition to pointing out the women's lost identities. However, the memory of the genocide has been the basic building block of the Armenian national identity down to the present day (Tachjian, 2009). To add, Resnik (2003) describes that the feeling of fear noted in the nations tragic past has become the people's common denominator.

\subsection{The Road from Home}

David Kherdian in his book "The Road from Home" records and reminds the world of another infamous holocaust in our century. Kherdian wrote his mother's story. Veron Dumehjian was born to a prosperous Armenian family, who lived in the Armenian quarter of Azizya in Turkey. Her early childhood was idyllic, until in 1915 the Turkish government, after years of persecution of its Christian minorities, decided to rid Turkey of its Armenian population (Kherdian, 1979). Veron lived in the Armenian quarter and was deported with her family and survived incredible hardships and suffering until, at the age of 16, she left for America as a "mail-order" bride. Kherdian's story of his mother is a story of courage, survival and hope (Kherdian, 1979).

Armenian women, who were among the victims of the genocide, had gone through dreadful experiences. They were rejected by their national community and isolated as a result. Aharonian 1919, states "our nation cannot profit from such as these anymore." Additionally, the Danish missionary's letter to the Archbishop Ardavast Surmeyan expressed the negative attitude against those women (Tachjian, 2009).

Tachjian (2009) stated, the letter affirms,

I have received your letter about the woman, Jeranig, but I profoundly suggest not to be able to touch the case, as it is entirely against my rule to receive Mohammedan children except in the case, when the father gives them up on his own account...However, from a purely Armenian point of view, I do not approve of 
these half-cast children. They are no good anyhow. My advice is to send her back. Why should we trouble to educate these foreign children, when we have so many Armenian children in need.

It is clear that women and children were often regarded as spoils of war, slaves, or even objects of sexual slavery. Thus, rather than being physically destroyed, women and children were transferred from one group to another, always with the idea of changing their national identity. That certifies these survivors' memories that explain the conditions under which Armenian children disappeared from the refugee caravans at the stations where they stopped (Tachjian, 2009). However, Ajemian-Ahnert (2007, p.94) mentioned this when her mother remembered "Arsen, the little boy, disappeared from the caravan." Additionally, a majority of the women had lost their husbands and other family members, many had been raped, and all their possessions had been stolen from them during the deportation. They had endured famine and occasionally given birth to illegitimate children. The group of women who had undergone these terrible experiences was often shunned by the other refugees as well. This was one reason that, simply in order to survive, some of them became prostitutes in large towns such as Aleppo, Damascus or Baghdad. Others, kidnapped by Muslims and forcibly married, had given birth to children, and after the war, they continued to live in their new homes. Ajemian-Ahnert (2007) described this situation when she mentioned what happened to her mother and how she was raped and then married to a Muslim man.

Such was the complicated situation that Armenian women faced in this period. But from 1917 on, the situation changed; now it was the Armenians themselves who began to look for their women, girls and children among the Arab tribes, urban Muslim families, or Turkish orphanages, gathering them with the aim of returning them to the national community. These efforts reveal all the contradictions and difficulties of such a project, especially as they were informed by the ideological principles of rebuilding and reconstructing the nation: in other words, the idea of "racial rebirth", "racial re-establishment" or "regeneration," which is a moment of a critical transition over the future of the nation. These expressions were in frequent use during the post-war era efforts to reintegrate orphans, abandoned girls and women (Tachjian, 2009).

On September 16, 1916, the Minister of the Interior, Talaat Pasha, stated to the government of Aleppo, "It was at first communicated to you that the government, by order of the Jemiet, had decided to destroy completely all the Armenians living in Turkey...An end must be put to their existence, however criminal the measures taken may be, and no regard must be paid to either age or sex nor to conscientious scruples" (Kherdian, 1979).

Here, I remember Euripides, 431 B.C.E saying "There is no greater sorrow on earth than the loss of one's native land." Armenians were deported, forced to leave their land, culture and identity and marched through the desert to reach the Middle East, the areas around Hama, Homs, Damascus, Egypt, Iraq, Lebanon, Kerek and Trans-Jordan. It is the generations that were born to these survivors that today form the majority of the Armenian Diaspora.

Thus, at the end of the World War I, a heterogeneous mass of several tens of thousands of Armenian survivors had settled in the newly established countries of the Middle East, such as Lebanon, Syria, Egypt, Palestine, Trans-Jordan and Iraq, which had passed through a national reconstruction stage.

\subsection{Interviewing Second Generation Armenian Women from the Middle East}

In order to relate the present and the future with the past, I interviewed two second generation female genocide survivors from the Middle East. The first one works as journalist in addition to her volunteer work in the Armenian club. She contributes in educating the young generation and keeping them involved in the Armenian community. She thinks "being Armenian is a continuous struggle in to keep the identity alive and live with the legacy of an injustice towards Armenia and non-recognition of the genocide, she concentrates on the difficulty to preserve the Armenian heritage, language and culture in the Diaspora" (Bannayan, November 15, 2009). As for being Jordanian, she mentions "it means to be a citizen of a moderate, forward thinking country in an unstable region." Additionally, "Armenian school was like home. It's where I became what I am today." As for the factors that are influential in preserving Armenian identity in the Middle East, she said, "clubs, schools are the most important in preserving identity. Small community makes solidarity a mist." As for her identity, she mentions a dual citizenship, Armenian-Jordanian but feels distinctly Armenian. Also, she describes her life as a Diaspora Armenian which means "being an outsider wherever you go...I became aware by being active in Armenian clubs and learning about history." She adds "All Armenians try to be good at what they do...they are straightforward and hardworking. I feel stronger connections to Armenians living in the Diaspora." Thus, in her response about preserving the Armenian identity in Jordan after a couple of generations, she emphasizes, "still there but will get more difficult with generations...It will get more difficult to preserve... but Armenians try to hold on to it more than other Diaspora communities." (Bannayan, November 15, 2009).

My interpretation is to point out the three cornerstones that preserve the Armenian Diaspora's infrastructure, the Armenian Church, the clubs, and the school. Such pillars are not unique to the Jordanian group. One finds a similar 
infrastructure in all countries that contain groups of the Armenian Diaspora. Additionally, William Saroyan, a famous American Armenian writer states, "For when two of them meet anywhere in the world, see if they will not create a New Armenia" (Saroyan, 2009).

The second person whom I interviewed was born in Haifa, lived in Ramallah and then relocated in Amman and has been living there ever since. She used to work with the United Nations Relief and Works Agency (UNRWA) for twenty eight years and currently is working in a habilitation / rehabilitation center for the physically challenged. She never went to an Armenian school because there were none in Ramallah. She adds, "I am Armenian. My parents, grandparents and great grandparents were born in Western Armenia and left in 1914 during the massacre; being Armenian means that I come from a population who are survivors. After all that happened to them they survived and became citizens in the country where they are living." Moreover, she said, "Diaspora means when the Armenians fled Turkey and were scattered all around the world. I first became aware of it when I first went to school; all my classmates had maternal and paternal uncles, aunts, grandparents and cousins. All my relatives were dead or scattered around the world. I haven't met most of them. My parents explained to me about Diaspora." However Ajemian-Ahnert (2007) explained the Diaspora situations that all Armenians live in due to the genocide which created a new Diaspora identity for all Armenians. And when I asked her about her feelings toward Jordan she mentioned, "this is the place where I grew up. I feel part of the community." (Djyerian, October 11, 2009). (figure 1)

Utilizing Figure (1) is an attempt to explain Diaspora identity and educate about the factors that are influenced by it. For example, language, identity, history and religion have homes in the context of culture, in daily activities, in social institutions and in ritual performances and ceremonies (King, 2001). Armenian identity continues in the Armenian world. For Armenian youth who grow up in the Diaspora, the Armenian world is the first world they come to know in the course of "living it" through active participation and involvement (King, 2001). The continuing maintenance of the Armenian language, history, religion and culture offers a strong prospect for effective and successful identity preserving (King, 2001). However, the influential factors in preserving Armenians' identity in Jordan are "the two Armenian clubs that are in Amman help a lot about keeping the Armenian culture and telling others about it via the activities they having during the year. Being a close knit community is the core of Armenians' solidarity." (Djyerian, October 11, 2009).

This quote assures that Armenians up to now succeeded in maintaining their unique cultural heritage. Moreover, the Armenian Church, school and clubs played a tremendously important role in Jordan.

As a child I recall my grandmother's stories. She used to tell us "back in home churches and schools preserved the community..."

My grandparents are from the Western part of Armenia (Adana). They were exposed to extermination and genocide in 1915. They survived despite this genocide and culturalicide (Parakash and Stuchul, 2004). For me as an Armenian, the extermination is still a reality. Are we now like we were when we used to live on our ancestral land? No, we have lost a lot of our characteristics and culture since then (Derderian-Aghajanian, 2009). Hall (1996) describes lost identities as "questions of using the resources of history, language and culture in the process of becoming rather than being: "who we are" or "where we came from." However, as much as what we might become, how we have been represented and how that bears on how we might represent ourselves."

Willinsky (2002) supports this saying by asking "who-belongs-where" and argues that this is great source of inequity and miseducation. To conclude, history, culture, and language affect one's identity but one should benefit from these for the future as culture is embedded in literacy (Harris Wills, 2003).

\subsection{Other Ethnic Groups and Their Opinion about the Genocide}

In a letter from a friend to her mother describing her journey to her grandparents land, she mentioned, "Let me take a break to sort of update you all on a little of my family's history - many of you may already know this, but some of you are probably thinking... Basically go back to what you might have learned in history class about the Ottoman Empire during World War I. Over 100 years ago my family was living in this small village called Karabash... they were farmers and sheepherders. This was a predominantly Christian village made up of Armenians and Arabs who shared a common religion. This was before lines were drawn on a map to split up the whole Ottoman Empire into countries we now know of to be Syria, Turkey, Lebanon, Iraq, etc. In 1915, the Turkish government directed a push to get rid of all of the Christians from this area of Turkey. If you want to do your own research - this is now known of as the Armenian Genocide. Turkey does not really admit or acknowledge this part of their history - so this is a sensitive subject that I was warned not to talk too freely about here, which I've tried not to do. My family was forced out of this village of Karabash. Just like any other genocide - men or soldiers came first and started killing the other men of the village and the women and children were forced to run." (Daud, September 8, 2010). This letter reminds me about my grandmother's stories. She described how the Turks came to their home knocking at the door and asking for her old 
father she said, "I was the oldest and had three other brothers and one sister we all cried with my mother and never saw our father again, later we were told that he was killed as for my grandfather who was also from the same area (Adana) and being the priest's son saw his two brothers being killed and never saw his parents again, Somehow he fled to Jaffa-Middle East. If you look at a map and just see the distance that Armenian people walked to reach to the Middle East it is absolutely amazing that they had to walk this far and made it...women and children why? All because they had different religion. Ajemian-Ahnert (2007) mentioned in her book, "In 1915, Armenian Christians in Turkey were forced to convert to Islam, barred from speaking their language, and often driven out of their homes as the Turkish army embarked on a widespread campaign of intimidation and murder." Today, this same exact story applies to many countries and regions...genocide is all the same. Ajemian-Ahnert (2007) describes what is happening to the people in Darfur and how this is similar to what happened to her mother.

George Bernard Shaw, an Irish dramatist and socialist states, "If history repeats itself, and the unexpected always happens, how incapable must Man be of learning from experience." This quote illustrates what is happening now in Darfur and relates to what happened in Ani, the ruined city in Turkey near the Armenian border.

\subsection{Because of My Name: Ani: Which Is the Bridge between Armenia, Turkey, and the Diaspora}

Ani is the ruins of the capital of medieval Armenia and was named as the City of 1001 churches. It is near the Arpaçay River (Akhurian River in Armenian), a tributary of the Aras River. The Arpaçay River constitutes the border between Armenia and Turkey. Ani takes its name from the ancient Urartian fertility goddess Anahid. The city collapsed in an earthquake in 1319. It is about 48 kilometers from the city of Kars (Artsakank, 2010).

In the $19^{\text {th }}$ century the ancient ruins of Ani was used as the site of the annual spring reunion and pilgrimage point of the Armenians (Armenian Heritage, 2010).

Religious and patriotic Armenians from all over the world would camp together to rejoice in the glory of the past and share in their vision of the future (Armenian Heritage, 2010). These reunions lasted well into 1915, until Turkey perpetrated the genocide on the Armenian nation, and then Ani became silent (Armenian Heritage, 2010). The irony is Turkey, who committed the genocide, utilizes the world famous ruins of Ani as a tourist attraction, but states nothing of its past with regard to the Armenians (Armenian Heritage, 2010).

Nowadays, most observers have noted that civil society "projects that would bring people on both sides of the border closer would also prepare the groundwork to rebuild the ancient Silk Road Bridge at Ani, which once spanned the Arpaçay River separating Turkey from Armenia." (Artsakank, 2010).

\section{Conclusion}

The Armenian genocide is a big pain that every Armenian carries in his heart, the memories of our ancestors who lost their lives. Stories are memories to keep for our generations. To tell the history of parents, grandparents and great-grand parents who survived the Armenian Genocide. What did they see? How was their journey from their homeland to their new destination, and their sufferings throughout their routes?

Henry Morgenthan, the U.S. ambassador to the Ottoman Empire in 1913-16, describes the Turks as masters in devising new methods of torture, but he is discreet about the details. He writes: "I have by no means told the most terrible details, for a complete narration of the sadistic orgies of which these Armenian men and women were the victims can never be printed in an American publication" (Peroomian, 2008).

\section{References}

Armenian Heritage. (The City of Ani). (2010). [Online] Available: http://www.armenianheritage.com/peani.htm (December 13, 2010)

Armenian National Committee of America (anca). (2010). [Online] Available: http://www.natctr.org/index.php?id=14 (November 27, 2010)

Ajemian-Ahnert, M. (2007). The Knock At The Door: A Journey Through The Darkness of The Armenian Genocide. Beaufort Books: New York.

Armenian National institute (ANI). (2010). [Online] Available: http://www.armenian-genocide.org/ (November 18, 2010)

Artsakank. (2010). [Online] Available: http://artsakank.com.cy/en/news/general/2010/ani-dialogue-strengthen-ties-between-turkish-armen (December 1, 2010)

Derderian-Aghajanian, A. (2009). Armenian's Dual Identity in Jordan. International Education Studies, 2(3), 34-41

Downing, C. (1972). Armenian Folk Tales and Fables. Oxford University Press. 
Freeman, J. (2007). The Knock at the Door: A Journey through the Darkness of the Armenian Genocide. Booklist, 103(17), 65. Retrieved December 1, 2010 from MasterFILE Premier database.

Hall, S. (1996). Who needs “Identity?” In S. Hall and P. Du Gay (Eds.), Question of cultural identity (pp.1-17), Thousand Oaks, CA: Sage.

Harris, V.J. (2003). Multiculturalism, literature, and curriculum issues, In J. Flood, D.

Kherdian, D. (1979). The Road from Home: The Story of an Armenian girl. Greenwillow Books, A Division of William Morrow and Company, INC: New York.

King, K. A. (2001). Language revitalization process and prospects: Quichua in the Ecuadorian Andes. Clevedon, UK: Multilingual Matters.

Mendoza, J., and Reese, D. (2001). Examining multicultural picture books for the early childhood classrooms: Possibilities and pit falls. Early Childhood Research and Practice, 3(2), 1-31

Okoomian, J. (2002). Becoming White: Contested History, Armenian American Women, and Racialized Bodies. Melus, 27(1), 213-237

Panossian, R. (2002). The Past as Nations: Three Dimensions of Armenian Identity, Geopolitics, 7(2), 121-146

Parakash, M.S., and Stuchul, D. (2004). McEducation marginalizes: Multiverse of learning-living in grassroots commons, Educational Studies, 36(1), 58-72

Peroomian, R. (2008). And Those Who Continued Living in Turkey after 1915: The Metamorphosis of the Post-Genocide Armenian Identity as Reflected in Artistic Literature. Yerevan: Armenian Genocide Museum-Institute.

Resnik, J. (2003). Sites of memory' of the holocaust: shaping national memory in the education system in Israel, Nations and Nationalism, 9(2), 297-317

Saroyan, W. (2009). Words about Armenia. [Online] Available: http://philgreen.posterous.com/the-poem-of-william-saroyan-th (April 24, 2009)

Stephens, J. (1992). Language and ideology in children's fiction. New York: Longman.

Surmelian, L. (1968). Apples of Immortality: Folktales of Armenia. Berkely: University of California Press.

Tachjian, V. (2009). Gender, nationalism, exclusion: the reintegration process of female survivors of the Armenian genocide. Journal of the association for the study of ethnicity and nationalism, 15(1), 60-80

The Armenian General Benevolent Union (AGBU). [Online] Available: http://www.agbu.org/aboutagbu/default.asp (November 27, 2010)

Willinsky, J. (2002). The nation-state after globalization, Educational Studies, 33(1), 35-53

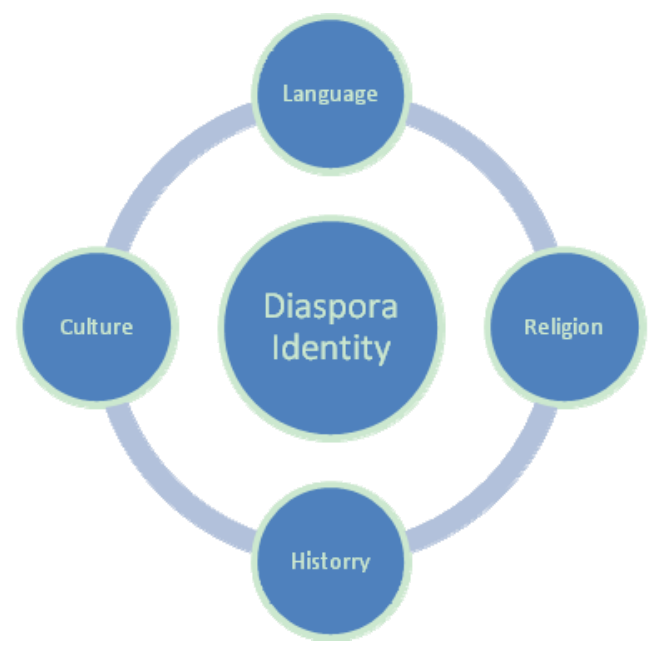

Figure 1. Diaspora Identity 